\section{Atmospheric pollution effects on childhood health: an environmental study in the Paraíba Valley}

\section{Efeitos da poluição atmosférica na saúde infantil: um estudo ecológico no Vale do Paraíba}

Luiz Fernando C. Nascimento 1

Maria Carolina C. Módolo 2

João A. Carvalho Jr. 3

\section{Abstract}

Objectives: to estimate correlation between atmospheric pollutants and the number of children admissions by respiratory disease in the year 2001.

Methods: this is an ecological study of time series. The data on the atmospheric pollutants were obtained at CETESB and the data on hospital admissions were obtained at the Medical Archive Service of the Taubaté University Hospital, in Taubaté. In order to study the correlation of pollutants concentration values between themselves and with the admissions, the Pearson correlation technique was utilised. The relative risks for admission by respiratory disease were estimated comparing the quartiles of the pollutant agents with values of the first quartile. The adopted statistical significance was alpha $=5 \%$.

Results: one hundred and fifty eight children were admitted with respiratory disease in the year 2001 (30\% of annual admissions). The pollutants were correlated between themselves. There was a positive correlation between the number of admissions and the concentrations of sulphur dioxide and particulate material. There was an increase of $25 \%$ in the admission risk when comparing the fourth and the first quartiles.

Conclusions: there was positive correlation between admission by respiratory disease and the concentration of atmospheric pollutants.

Key words Air pollution, Respiratory tract disease, Environmental health, Child health

\section{Resumo}

Objetivos: estimar as correlações entre os níveis de poluentes atmosféricos e o número de internações por doença respiratória em crianças, em hospital universitário.

Métodos: trata-se de um estudo ecológico de série temporal. Os dados sobre poluentes atmosféricos foram obtidos junto à CETESB e os dados sobre internação hospitalar, junto ao SAME do Hospital Universitário de Taubaté, Brasil. O estudo se refere a dados e internação do ano de 2001. Para estudar as correlações dos valores dos poluentes entre si e entre as internações, utilizou-se da técnica de correlação de Pearson. Foram estimados os riscos relativos para internação por doença respiratória comparando os quartis dos agentes poluentes com os valores do primeiro quartil. A significância estatística adotada foi alfa $=5 \%$.

Resultados: foram internadas 158 crianças com doença respiratória no ano de 2001 (30\% do total de internações no ano). Os poluentes estiveram correlacionados entre si e houve correlação positiva, entre o número de internação e dióxido de enxofre e material particulado; houve aumento de $25 \%$ no risco de internação comparando o quarto quartil e o primeiro quartil.

Conclusões: houve correlação positiva entre número de internações por doenças respiratórias e poluentes atmosféricos.

Palavras-chave Poluição do ar, Doenças respiratórias, Saúde ambiental, Saúde infantil 


\section{Introduction}

The contamination of the atmosphere by human activities has been occurring for almost 500 years. Considering that the atmospheric pollutants reach the individual mostly by breathing, it is expected that their main effects be in the respiratory tract.

Exposure to environment pollutants is recognised as an important factor for children hospital admissions, ${ }^{1}$ school absence, ${ }^{2}$ intra-uterine mortality, ${ }^{3}$ and even congenital malformation. 4 Sulphur dioxide $\left(\mathrm{SO}_{2}\right)$, ozone $\left(\mathrm{O}_{3}\right)$ and particulate material with aerodynamic diameter lower than $10 \mathrm{~mm}\left(\mathrm{PM}_{10}\right)$ are among the most hazardous pollutants.

Sulphur dioxide is known as a respiratory tract irritant which causes decrease of lung function 5 and even pulmonary necrosis in animals. ${ }^{6}$ It was recently shown that increase of $\mathrm{SO}_{2}$ levels yielded increase of pneumonia and flu cases in the elderly. ${ }^{7}$ The main sources for this pollutant are coal and petroleum derivatives. Sulphur dioxide is easily absorbed in the upper respiratory tracts and it deposits in the lower portion of these tracts and in the pulmonary parenchyma.

Ground level ozone results from photochemical reactions between nitrogen oxides, provided by oxidation of the nitrogen present in the air and/or in the fuel, and solar radiation. 8 Ozone can cause decrease of the lung function, lung inflammation and it can reach lung alveoli. 5 The pollutant is also a very strong oxidiser and, as such, it can participate in inner and outer cellular reactions, involving enzymes which are important for metabolism.

Particulate material originates mainly from the burning of fossil fuels It can have a half life ranging from days to years, and it is associated with increases of respiratory symptoms and diseases in children, and worsening of asthma cases.9,10 More recently, this pollutant has been shown to be associated with low birth weight 11 and infant mortality 12 The particulate material can also reach the alveolli thinnest respiratory tracts.

One of the effects of the atmospheric pollution on childhood health is the increase of hospital admissions by respiratory diseases. 13 There is correlation between the lowest temperatures and hospital admis sions.

The objective of this work is to estimate the correlation between the level of atmospheric pollutants and the number of children admissions by respiratory diseases in a university hospital.

\section{Methods}

This is an ecological study of time series, where all children hospital admissions were counted for children up to seven years of age. The period was January 1 to December 31, 2001. The total number of admissions for this age group was also identified. The data were obtained at the hospital Medical Archive Service (SAME).

The unit was the University Hospital of Taubaté, Brazil. The city of Taubaté is located at $120 \mathrm{~km}$ East of São Paulo and its population is on the order of 250,000 inhabitants. Taubaté locates between Mantiqueira and Sea Mountain; the wet climate included November to March months and the temperatures can be so higher as $35^{\circ} \mathrm{C}$. In winter the minimal temperatures are near to $10^{\circ} \mathrm{C}$. Its geographic situation is $24^{\circ}$ South latitude and $44^{\circ}$ West longitude.

The respiratory diseases considered in this work are those corresponding - in the International Classification of Diseases, 14 10th revision, to the group diagnostics $\mathrm{J} 12$ to $\mathrm{J} 22$, J45 and J46. The number of hospital admission by respiratory diseases was the dependent variable.

Daily data of humidity, in percents, and temperature, in Celsius degrees, and of the pollutants $\mathrm{SO}_{2}$, $\mathrm{O}_{3}$ and $\mathrm{PM}_{10}$ concentrations were obtained at the São Paulo State Environmental Agency (CETESB) section of Taubaté were the independent variables.

For all the three pollutants, data collection started during the first hour of the day and encompassed 24 hours. Concentrations were determined in $\mathrm{mg} / \mathrm{m}^{3}$. Concentrations of $\mathrm{PM}_{10}, \mathrm{SO}_{2}$ and $\mathrm{O}_{3}$ were measured using the monitor beta, coulometry, and chemiluminescence techniques, respectively.

There were built three days mobile averages to pollutants to estimate its effect on hospital admission. There were built tables with one day lag and two days lag to number of hospital admission and estimated the correlation between these values and the independent variables.

The correlation between the variables was estimated by the Pearson correlation coefficient.

The relative risks for hospital admission by respiratory disease were estimated by comparing the second, third and fourth quartiles of the pollutant agents with the values of the first quartile. Confidence intervals of $95 \%$ were constructed. The Epiinfo 6.04 program was used for data compilation and analysis. The adopted statistical significance in this study was alpha $=5 \%$. 


\section{Results}

There were 526 children hospital admissions in 2001 . One hundred and fifty eight hospital admission $(30 \%)$ were due to respiratory diseases. The latter corresponds to a daily average of 0.58 admission $(\mathrm{dp}=0.79)$, varying between 0 and 4 admissions per day.

Table 1 presents the number of admissions, the humidity, the temperatures, and the $\mathrm{SO}_{2}, \mathrm{O}_{3}$ and PM10 concentrations, with their respective standard deviations and interval amplitudes.
Table 2 presents the correlation matrix between the variables, with the respective $p$. It can be observed that there was correlation of the pollutants concentrations between themselves. Also, there was correlation between $\mathrm{SO}_{2}$ and $\mathrm{PM}_{10}$ concentrations and the number of hospital admissions. It can observed the correlation between the pollutants and one day lag. It was found a positive correlation between temperature and $\mathrm{PM}_{10}$ with hospital admission one day lag $(p<0.05)$. There were not correlation between other pollutants, humidity, and mobile average and hospital admission.

Table 1

Mean values, standard deviations and interval amplitudes for daily hospital admissions and SO2, O3 e PM10 concentrations.

\begin{tabular}{lccc}
\hline & Mean value & Standard deviation & Amplitude \\
\hline Admissions (per day) & 0.58 & 0.79 & $0-4$ \\
$\mathrm{SO}_{2}(363) *, \mu \mathrm{g} / \mathrm{m}^{3}$ & 5.9 & 3.6 & $1.0-34.0$ \\
$\mathrm{O}_{3}(363), \mu \mathrm{g} / \mathrm{m}^{3}$ & 66.3 & 24.3 & $10.0-139.0$ \\
$\mathrm{PM}_{10}(358), \mu \mathrm{g} / \mathrm{m}^{3}$ & 37.7 & 20.4 & $10.0-150.0$ \\
Temperature (363), $0 \mathrm{C}$ & 19.6 & 2.9 & $4.4-34.4$ \\
Humidity (362), $\%$ & 84.0 & 8.4 & $47.1-98.5$ \\
\hline
\end{tabular}

* The figures between parentheses correspond to the total number of days in which the respective pollutant concentration was measured.

Table 2

Matrix of correlation between the variables and the respective $p$.

\begin{tabular}{|c|c|c|c|c|c|}
\hline & Admission & $\mathrm{SO}_{2}$ & $\mathrm{O}_{3}$ & $\mathrm{PM}_{10}$ & Temp \\
\hline Admission & 1,00 & & & & \\
\hline $\mathrm{SO}_{2}$ & $0,12^{*}$ & 1,00 & & & \\
\hline $\mathrm{O}_{3}$ & $-0,06$ & $0,30 *$ & 1,00 & & \\
\hline $\mathrm{PM}_{10}$ & 0,10 * & 0,71 * & $0,22 *$ & 1.00 & \\
\hline Temp & -0.10 & $-0.18^{*}$ & $0.26^{*}$ & $-0.24^{*}$ & 1.00 \\
\hline Humidity & 0.33 & -0.20 & -0.10 & -0.20 & 0.05 \\
\hline 1 day lag & & 0.00 & -0.07 & $0.12 *$ & -0.11 * \\
\hline
\end{tabular}

$* p<0,05$ 
Table 3 shows the relative risks between the second, third and fourth quartiles for hospital admissions according to each pollutant considered in this study, comparing with data of the first quartile. It can be observed that an increase of $46 \mu \mathrm{g} / \mathrm{m}^{3}$ of particulate material increases in $24 \%$ the risk of hospital admission for the paediatric population of this study. An increase of $8.5 \mu \mathrm{g} / \mathrm{m}^{3}$ of sulphur dioxide increases in $25 \%$ the risk of admission for the same population. It should be pointed out that these data do not present statistical significance, possibly because of the small sample size.

Figures 1-4 show the daily distribution of temperature and the pollutants concentration. Increase of $\mathrm{SO}_{2}$ and $\mathrm{PM}_{10}$ concentrations occurred between days 150 and 210, which correspond to the coldest months in the region. There is no observed trend for the ozone concentration distribution because the origin of this pollutant is not associated to low temperatures.

\section{Table 3}

Relative risk (RR), for a confidence interval of $95 \%$ (CI95\%) for admissions, according to the pollutants quartiles, and respective $p$.

\begin{tabular}{|c|c|c|}
\hline & RR (Cl95\%) & p \\
\hline \multicolumn{3}{|l|}{$\mathrm{PM}_{10}$} \\
\hline 1st Quartile $(10-23) *(19.0) * *$ & 1.00 & \\
\hline 2nd Quartile (24 - 31) (27.0) & $1.15(0.81-1.64)$ & 0.44 \\
\hline 3rd Quartile (32 - 44) (37.0) & $0.98(0.66-1.42)$ & 0.87 \\
\hline 4th Quartile (45 - 150) (65.0) & $1.24(0.92-1.82)$ & 0.15 \\
\hline \multicolumn{3}{|l|}{$\mathrm{SO}_{2}$} \\
\hline 1st Quartile (1 - 3) (2.6) & 1.00 & \\
\hline 2nd Quartile (4 - 5) (4.5) & $0.97(0.70-1.35)$ & 0.88 \\
\hline 3rd Quartile (6 - 7) (6.5) & $0.94(0.65-1.38)$ & 0.76 \\
\hline 4th Quartile (8 - 34) (11.2) & $1.25(0.90-1.73)$ & 0.18 \\
\hline \multicolumn{3}{|l|}{$\mathrm{O}_{3}$} \\
\hline 1st Quartile $(10-48)(37.0)$ & 1.00 & \\
\hline 2nd Quartile (49-67) (57.8) & $0.81(0.60-1.11)$ & 0.19 \\
\hline 3rd Quartile (68 - 81) (73.3) & $0.77(0.54-1.11)$ & 0.15 \\
\hline 4th Quartile (82 - 139) (98.2) & $0.89(0.66-1.22)$ & 0.47 \\
\hline
\end{tabular}

* Quartile amplitude $\left(\mu \mathrm{g} / \mathrm{m}^{3}\right) ;$ ** quartile mean values $\left(\mu \mathrm{g} / \mathrm{m}^{3}\right)$ 
Daily distribution of ozone $\left(\mu \mathrm{g} / \mathrm{m}^{3}\right)$ during 2001 .

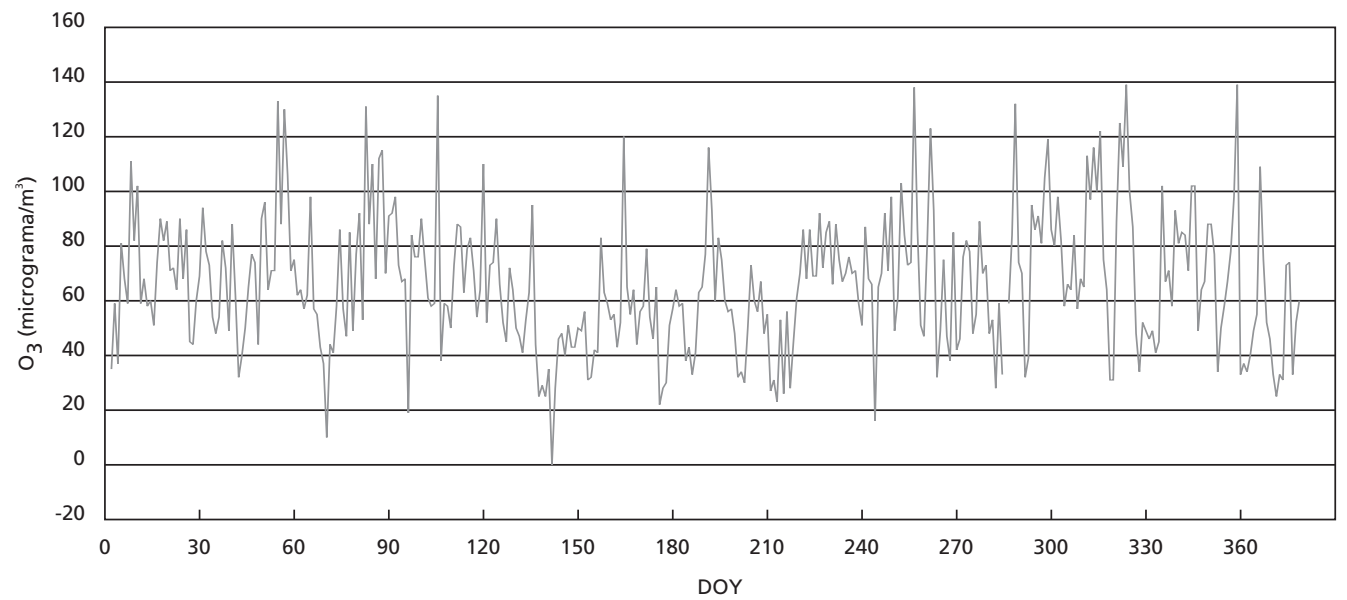

DOY = day of the year

Figure 2

Daily distribution of $\mathrm{PM}_{10}\left(\mu \mathrm{g} / \mathrm{m}^{3}\right)$ during 2001 .

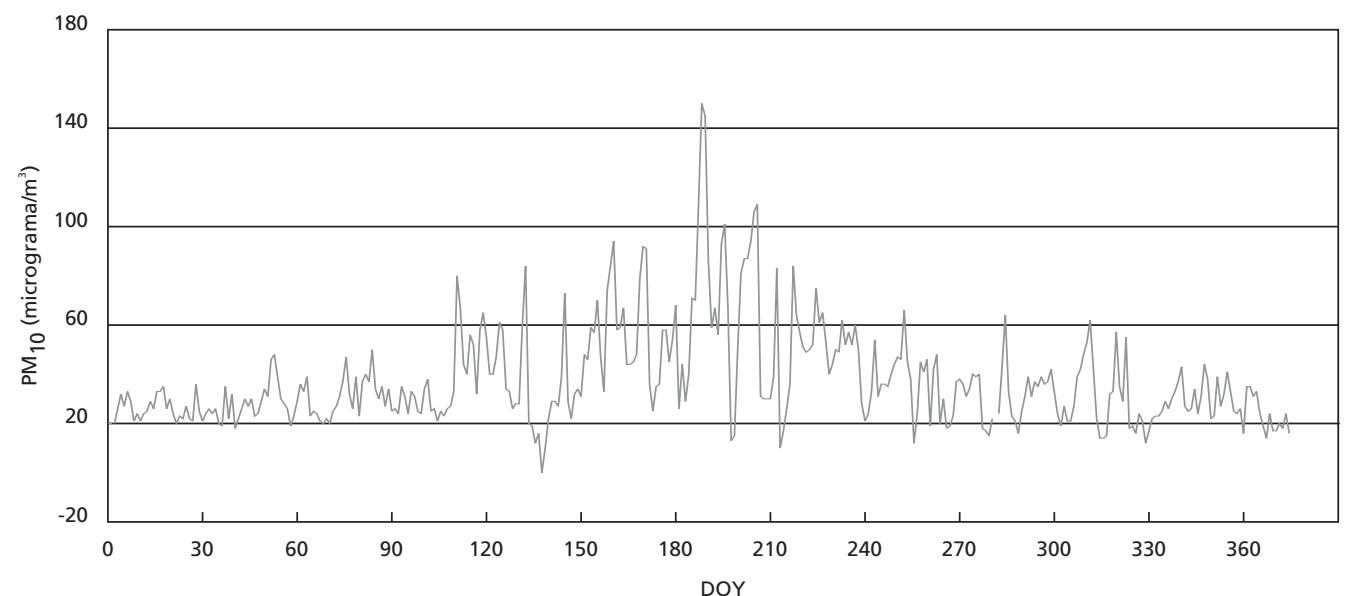

DOY = day of the year 
Figure 3

Daily distribution of $\mathrm{SO}_{2}\left(\mu \mathrm{g} / \mathrm{m}^{3}\right)$ during 2001 .

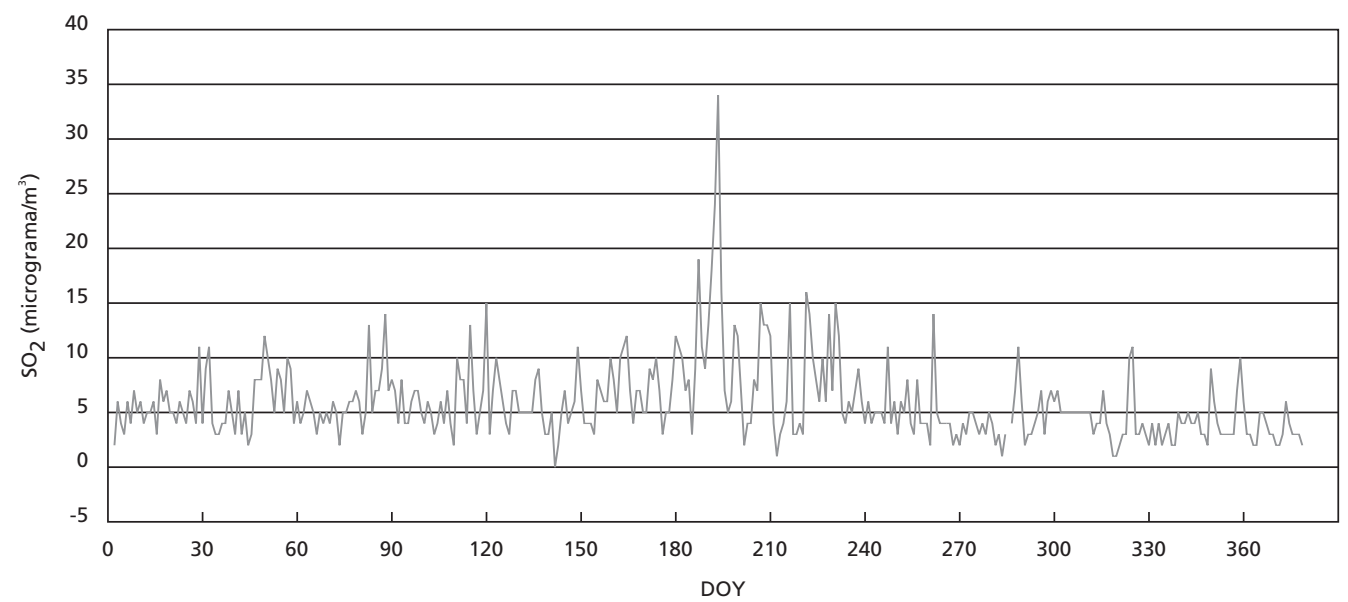

DOY = day of the year

\section{Figure 4}

Daily distribution temperature (0 C) during 2001.

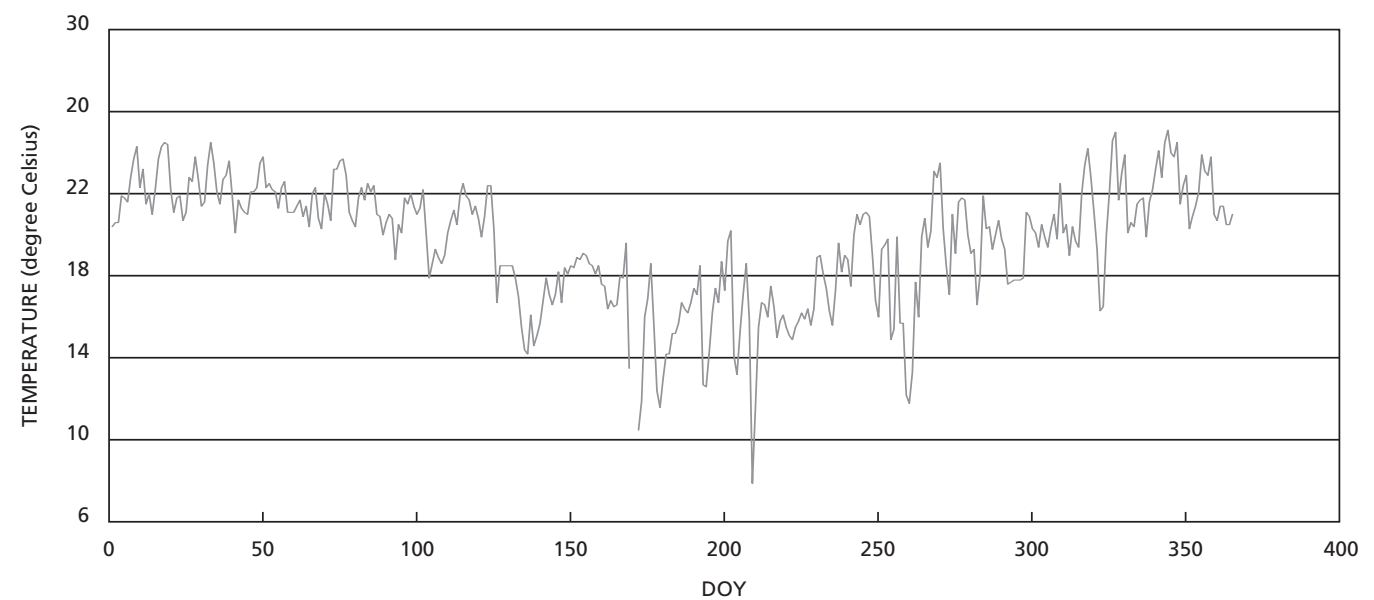

DOY $=$ day of the year 


\section{Discussion}

The dissemination, through scientific articles, of problems caused by atmospheric pollution in human health, especially in children, has contributed to a great extent for the control and decrease of emission of the associated pollutants. Pollution can affect healthy people and those who have history of previous diseases, and it may act as a responsible agent in the disease process. Studies of time series have shown the correlation between the level of pollutants and the number of hospital admissions by respiratory diseases. 1,3

An important aspect that needs to be considered is the inexistence of studies on the effects of atmospheric pollution on health conducted in centres outside the geographical sphere of the metropolitan São Paulo.

This study showed the distribution of the pollutants according to seasonal aspects and also the positive correlation, with statistical significance, of $\mathrm{PM}_{10}$ and $\mathrm{SO}_{2}$ atmospheric concentrations with the number of children hospital admissions. The values presented here agree with those presented in other studies. 1,13

A difficulty of ecological studies for which the geographical region is defined is that it is unknown if the individual acquired the disease in the same region of the study and if the disease was really caused by the pollutant agents under consideration. There is a high degree of reliability in the data presented here because they were obtained in a University Hospital. There are other questions with no direct answer: not every person that acquires a respiratory disease looks for medical services and not every one that looks for medical services is admitted in the hospital. Therefore, the parcel admitted in the hospital represents a fraction of those who were really sick. 15

The positive correlation found in this work for the number of admissions and the levels of concentrations of $\mathrm{SO}_{2}$ and $\mathrm{PM}_{10}$ were also reported in other studies. Also, the lowest temperatures have an important role with respect to medical admissions. The levels of these pollutants in this work were lower than those observed by Braga et al., 13 who conduct- ed his work with data of the São Paulo metropolitan region. Another fact was the correlation between hospital admission with a lag in $\mathrm{PM}_{10}$ level; this pollutant has a direct effect and an effect one day after the exposure. So, several hospital admission occurred by $\mathrm{PM}_{10}$ level of anterior day.

Regarding the ozone, there was no correlation of the pollutant level with the number of hospital admissions. The average values observed are similar to those presented by Braga et al. ${ }^{13}$ This pollutant showed concentration peaks in hot periods as well as in cold periods. This fact is explained by the higher level of solar radiation during the summer days and by the higher stability of oxidant precursors in the atmosphere during the winter days due to worse conditions for dispersion. Ozone has been shown to be associated to asthma, ${ }^{9}$ coughing crises, 16 and decay of lung function. ${ }^{17}$

It can be observed that an increase in the concentration of $\mathrm{SO}_{2}$ of $8.5 \mu \mathrm{g} / \mathrm{m}^{3}$ increases the risk for hospital admission by respiratory disease in about $25 \%$. The same happens for an increase in the concentration of $\mathrm{PM}_{10}$ of $46 \mu \mathrm{g} / \mathrm{m}^{3}$. However, these relative risk values for hospital admission did not present statistical significance, probably due to the sample size.

It is important to point out that the pollutants are not generated only in the region of Taubaté, but also in other centres. The pollutants generated in the metropolitan São Paulo can, depending on wind conditions, reach distances up to $300 \mathrm{~km}$. As Taubaté is located in a valley in which and the usual winds blow from west to east, may "import" these pollutants. 10

Regarding the analysis technique utilised in this work, if there were a larger time series with two or three year records, there would be the possibility of using the Poisson regression, in view of the fact that the present data are considered rare events, models with moving averages, and auto regressive models, because these models are more adequate for larger time series.

Therefore, a correlation between two pollutants $\left(\mathrm{SO}_{2}\right.$ and $\left.\mathrm{PM}_{10}\right)$ and hospital admissions by respiratory diseases is evidenced in the present work. In so it is a positive correlation between the pollutants. 


\section{Acknowledgment}

The authors are grateful to CETESB, who furnished data about pollutant records. Luiz Fernando C. Nascimento acknowledges to Fundação para o Desenvolvimento da UNESP (FUNDUNESP) (grant number 1032/04)

\section{References}

1. Lin CA, Martins MA, Farhat SCL, Pope CA III, Conceição GMS, Anastacio VM, Hatanaka M, Andrade WC, Hamaue WR, Böhm GM, Saldiva PHN. Air pollution and respiratory illness of children in São Paulo, Brazil. Paediatr Perinat Epidemiol 1999; 13: 475-88.

2. Park H, Lee B, Há EH, Lee JT, Kim H, Hong YC Associations of air pollution with school absenteeism due to illness. Arch Pediatr Adolesc Med 2002; 156: 1235-9.

3. Pereira LAA, Loomis D, Conceição GMS. Braga ALF, Arcas RM, Kishi H, Singer JM, Böhm GM, Saldiva PHN. Association between air pollution and intrauterine mortality in São Paulo, Brazil. Environ Health Perspect 1998; 106: 325-9.

4. Ritz B, Yu F, Fruin S, Chapa G, Shaw GM, Harris JA. Ambient air pollution and risk of birth defects in southern California. Am J Epidemiol 2002; 155: 17-25.

5. Committee of the Environmental and Occupational Health Assembly of the American Thoracic Society. Health effects of outdoor air pollution: state of the art. Am J Respir Crit Care Med 1996; 153 :3-50.

6. Giddens WE, Fairchild GA. Effects of sulfur dioxide on the nasal mucosa of mice. Arch Environ Health 1972; 25: 166-73

7. Martins LC, Latorre MRDO, Cardoso MRA. Gonçalves LFT, Saldiva PHN, Braga ALF. Poluição atmosférica e atendimentos por pneumonia e gripe em São Paulo, Brasil. Rev Saúde Pública 2002; 36: 88-94.

8. Carvalho JA, Lacava PT. Óxidos de nitrogênio (NOx). In Carvalho JA, Lacava PT. Emissões em processos de combustão. São Paulo: UNESP; 2003.

9. Abbey DE, Petersen F, Mills PK, Beeson WL. Long-term ambient concentrations of total suspended particulate ozone, and sulfur dioxide and respiratory symptoms in a non-smoking population. Arch Environ Health 1993; 48 : 33-46.
10. Fioravante C. Estufa que exporta poluição. Pesq Fapesp 2002; 71: 28-35

11. Bobak M. Outdoor air pollution, low birth weight, and prematurity. Environ. Health Perspect 2000; 108: 173-6.

12. Loomis D, Castillejos M, Gold DR, McDonnell W, BorjaAburto VH. Air pollution and infant mortality in Mexico City. Epidemiology 1999; 10: 118-23.

13. Braga ALF, Conceição GMS Pereira LAA, Kishi HS, Pereira JCR, Andrade MF, Gonçalves LFT, Saldiva PHN, Latorre MRDO. Air pollution and pediatric respiratory hospital admissions in São Paulo, Brazil. J Environ Med 1999; 2 95-102.

14. WHO (World Health Organization). International statistical classification of diseases and related health problems. 10th rev. Geneve: The Organization; 1997.

15. Lebrão ML. Evolução da morbidade hospitalar - Vale do Paraíba 1975/1988 [tese de livre-docência]. São Paulo: Faculdade de Saúde Pública da Universidade de São Paulo; 1994.

16. Schwartz J, Dockery DW, Neas LM, Wypij D, Ware JH, Spengler JD, Koutrakis P, Speizer FE, Ferris BG. Acute effects of summer air pollution of respiratory symptom reporting in children. Am J Respir Crit Care Med 1994; 150: 1234-42.

17. Spektor DM, Thurston GD, Mao J, He D, Hayes C, Lippmann M. Effects of single and multi-day ozone exposures on respiratory function in active normal children. Environ Res 1991; 55: 107-22.

Recebido em 30 de julho de 2004

Versão final apresentada em 5 de outubro de 2004

Aprovado em 28 de outubro de 2004 